\title{
The Impact of Client Characteristics on the Selection of the Audit Firm: An Empirical Study on the Egyptian Listed Companies
}

\section{Dr/ Dalia Muhammed Khairy El Madbouly}

Teacher of Accounting, Accounting Department, Faculty of Commerce, Damnhour University 


\title{
The Impact of Client Characteristics on the Selection of the Audit Firm: An Empirical Study on the Egyptian Listed Companies
}

Dr/ Dalia Muhammed Khairy El Madbouly ${ }^{1}$

\begin{abstract}
:
Auditor selection can be regarded as a matter of audit quality. This Research aims to identify the factors which affect the choice of the Audit Firm in case of an emerging capital market as Egypt. It provides empirical evidence on the association between the Audit Firm selection and their client firms' characteristics based on a sample of 101 firms listed in the Egyptian Stock of Exchange for the year ended 2013. Our findings indicate that certain firm's characteristics affect the choice of the Audit Firm. Actually, Firms' Size, Profitability, Foreign shareholdings, and the existence of a Foreign Board Member have significant positive influences on the selection of the Audit Firm. On contrast, firms' leverage, age, and ownership concentration are found to be non- significant to firm's choice of the external auditor in case of Egypt.
\end{abstract}

Keywords: client characteristics, auditor choice, audit quality, Big Four, Egypt.

\section{1- Introduction:}

1 Teacher of Accounting, Accounting Department, Faculty of Commerce, Damnhour University. Email: daliamkel@gmail.com 
Certainly, external auditors add value to the financial reports by assuring the proper and fair disclosure of a company's financial position. Actually, auditor selection can be regarded as a matter of audit quality. It is generally recognized that the audit markets are segmented into at least two categories, the Big 4 auditors and the NonBig 4 auditors. Big auditors are big international auditing firms which are used by most foreign scholars as the proxy for high audit-quality. In fact, the relationship between auditors and their clients is not simple. Companies with different firm characteristics demand varying levels of audit quality.

\section{2-Research problem:}

In fact, the relationship between the auditors and their clients is complex. There are a lot of arguments that the different characteristics of companies affect the varying demand for audit firms. Besides, there is a scarcity in researches examining the determinants of clients' choices of Audit Firm particularly in case of emerging markets as Egypt. Thus, this research questions whether the different firm characteristics affect the selection of the Audit Firm. The research asks the following questions:

1. Does firms' size affect the selection of the Audit Firm?

2. Does firms' profitability affect the selection of the Audit Firm?

3. Does firms' ownership affect the selection of the Audit Firm?

4. Does firms' leverage affect the selection of the Audit Firm?

5. Does firms' age affect the selection of the Audit Firm? 
6. Does the existence of a foreign member in the board of directors affect the selection of the Audit Firm?

\section{3-Research objective:}

This Research aims to identify the factors which affect the choice of Audit Firm in case of an emerging capital market like Egypt. This research examines the determinants of clients' choices of industry expert Big Four auditors, versus second Tier international auditors, and local auditors. This research aims to examine whether the firms' size, profitability, ownership structure, leverage, age, membership in the financial sector, foreign board members affect the selection of the Audit Firm in case of the Egyptian Capital Market.

\section{4-Research importance:}

This research contributes to the literature of auditor choice and firm characteristics by using an emerging market like the Egyptian capital market. Actually, there are few previous studies in this issue. Previous studies revealed that researchers reject the null hypotheses that clients are randomly allocated across the Audit Firms. Thus, many research efforts have been directed towards the auditor selection problem at the present time to determine the factors that affect the firm's choice of the Audit Firm. Accordingly, the results of this research will make a major contribution to the auditing literature and 
it will be useful to auditors, their clients and the regulators to understand the determinants of auditor selection by their clients.

\section{5-Research Methodology:}

To achieve the objective of this research, the research reviews the literature related to firm's choice of external auditor to conclude the determinants of external auditor selection and to develop the hypotheses of the research. Then, an empirical study is used to test the research hypotheses and to examine the association between certain firms' characteristics and the selection of the Audit Firm on a sample of listed firms in the Egyptian Capital Market.

\section{6-Research plan:}

This research is organized as follow: Section two presents an overview about the big Four Audit firms. Section three presents a review of the literature related to this issue. Section four presents the different client firm characteristics that may be associated with auditor selection and the research hypotheses are developed. Section five presents the sample, research design, and methods of analysis are described. Section six presents the results of the empirical study. Finally, the last section summarizes the empirical findings, conclusion, and suggests future researches in this area. 


\section{2- Big Audit Firms as High Audit-Quality:}

In fact, Audit Firms are classified into at least two main groups which are the Big Four and the non-Big Four Audit firms. The Big Four are the four largest international professional Audit Firms which offer audit, assurance, tax, consulting, advisory, corporate finance, and legal services. The Big Four audit firms are KPMG, Deloitte Touche Tohmatsu, PricewaterhouseCoopers and Ernst \& Young. Actually, none of the Big Four firms is a single firm; rather they are professional services networks. Each is a network of firms which are owned and managed independently, however these firms have entered into agreements with other member firms in the network to share a common name, brand and quality standards. Each network has established an entity to co-ordinate the activities of the network. In the case of KPMG, the co-ordinating entity is in Swiss, and in the other three cases of Deloitte Touche Tohmatsu, PricewaterhouseCoopers and Ernst \& Young the co-ordinating entity is in the United Kingdom (Big Four Firms Network, 2013).

Historically, this group was earlier known as the "Big Eight" which are Arthur Andersen, Coopers \& Lybrand, Ernst \& Whinney, Deloitte Haskins \& Sells, Peat Marwick Mitchell, Price Waterhouse, Touche Ross, and Arthur Young. This group was reduced to the "Big Six" and then to the "Big Five" through a series of mergers. Then the Big Five became the Big Four after the termination of Arthur Andersen in 2002 because of its involvement in the Enron scandal. 
Actually, it is widely accepted in the accounting literature that audit quality can be measured by the presence of a Big Audit Firm. Most scholars adopt Big Four auditors as the proxy for high auditquality. In reality, the market participants perceive the brand of the Big Four as an indicator of a higher audit quality in comparison to the audit services provided by non-Big Four audit firms.

In reality, Big Four audit firms are supposed to provide higher audit quality for several reasons. The first reason is that Big Four firms have stronger incentives to provide higher audit effort. These incentives arise from having more reputation capital to protect (DeAngelo, 1981). The second reason is that Big Four firms are expected to be more competent and perform greater regulatory examination. In fact, Big Four audit firms are larger in size which allows them to attract and maintain higher quality human resources and expertise (Dopuch and Simunic, 1982). In addition, Big Four audit firms also enjoy larger economies of scale when compared to smaller audit firms; making them more efficient in monitoring the level of audit quality they deliver (Watts and Zimmerman, 1981). Finally, Big Four auditors' large customer base subjects them less financially dependent on any given client, thus increasing their independence (DeFond et al., 2014).

\section{3- Literature review:}

In fact, auditor selection can be regarded as a matter of audit quality. However, previous researches show that there has been much 
debate over audit quality. Over the past 20 years, a number of researchers have tried to define audit quality. However, there is still no consensus on what audit quality is or how to measure it. DeAngelo (1981) defines audit quality as the market-assessed joint probability that a given auditor will both detect material misstatements in the client's financial statements and report the material misstatements. Therefore, according to DeAngelo's (1981) definition, audit quality is a function of the auditor's ability to detect material misstatements (technical capabilities) and reporting the errors (auditor independence). Palmrose (1988) defines audit quality in terms of level of assurance. Since the purpose of an audit is to provide assurance on financial statements, audit quality is the probability that financial statements contain no material misstatements. In fact, these definitions use the results of the audit, that is, reliability of audited financial statements to reflect audit quality (Chadegani, 2011).

On contrast, other Researchers have generally focused on the characteristics of the auditor and the audit team as critical parts of audit's inputs and hence guarantee audit quality. They have found that individual characteristics such as professional skepticism, specialist knowledge and the expertise of the auditor are important factors contributing to the quality of auditors' judgments and therefore to audit quality. In fact, recent empirical researchers suggest that big audit firms guarantee audit quality. Much of the literature finds evidence consistent with Big Four audit firms providing higher audit quality than non-Big four audit firms. 
Actually, many previous studies provided evidence that clients desiring higher quality audits select Big Four auditors (Fan \& Wong 2005). Francis (2004) also claims that audits of Big 4 auditors are of higher audit-quality than non-Big 4 auditors because Big 4 auditors can charge higher audit fee for higher audit quality through more audit effort and greater expertise of the auditor. Lennox and Pittman (2010) also claim that Big $\mathrm{N}$ auditors are associated with higher quality audit outputs, such as a lower likelihood of fraud. Wang and Qingquan (2011) provide evidence that the Big 4 auditors play a meaningful role in improving earnings quality across firms. Further, they find that clients of Big 4 auditors report lower unsigned discretionary accruals relative to the clients of non-Big 4 auditors.

Besides, Becker, DeFond, Jiambalvo, and Subramanyam, 1998; Francis, Maydew, and Sparks, 1999;and Kim, Chung, and Firth, 2003 provide evidence that a Big $\mathrm{N}$ Audit firm has a significant role in limiting the management opportunistic earning management using the discretionary accruals. Further, Rodríguez and Núñez (2009a) provide evidence that the Big 4 auditors impose accounting conservatism practices on their clients in order to reduce their risk exposure in contrast to the clients of the non-Big 4 auditors. Cano M., Núñez M., Sánchez S., (2012) provide evidence that the selection of a highly reputed auditor reduce the cost of capital across different countries from all over the world. Also Rodríguez, Núñez M., (2009b) provide evidence that Big 4 auditors' clients pay a lower cost of debt, thereby confirming the positive value of audit quality over the world. Leung 
and Cheng (2014) adopt Big 4 auditors as the proxy for high-audit quality. They provide evidence that certain corporate governance factors, ownership of the largest shareholders and percentage of independent directors in the board have significant positive influence on auditor choice.

Moreover, Ianniello G., Mainardi M., Rossi F., (2013) provide evidence that firms with better corporate governance select a Big Four audit firm. Also, Lin and Liu (2009) provide evidence that firms with weaker internal corporate governance mechanism are more likely to choose a low quality auditor versus a big four audit firm. In addition, Fan and Wong (2005) provides evidence that the choice of a Big 4 auditor compensates for a monitoring function in Asian firms with higher agency problems. Francis and Wang (2008) and Becker, et al. (1998) explain the difference between the Big four and non Big four is in the higher level of independence of Big 4 auditors. Big 4 auditors are expected to be more independent because they can expect more damages in the case of discovering an audit misstatement. Thus, audit failures will likely produce greater losses of reputation for Big 4 auditors, because they possess a greater reputational capital.

However, Boone, Khurana and Raman (2010) find little difference in actual audit quality but a more difference in perceived audit quality between Big 4 and second-tier firms from 2003 to 2006 in U.S. Also, Raghunandan and Rama (1999) Johnstone (2000); Johnstone and Bedard (2004) provide empirical evidence that the Big 
$\mathrm{N}$ auditors have incentives to choose less-risky clients to protect their reputation, lower litigation risk, and reduce regulatory scrutiny. Palmrose (1988) analyzed the relation between the audit litigation and the audit service quality. He reported that audits by the Big 4 were less likely to result in litigation. In addition, several scholars adopted Big 4 and non-Big 4 auditors to proxy for high-quality and low-quality audit, this is because Big 4 auditors possess a higher degree of industrial expertise and are less politically influenced by local governments (Chen, et al., 2001; Simunic \& Wu, 2009; Chen, et al., 2009; Guedhami, et al., 2009; Wang \& Xin, 2011). In summary, audit quality is associated to the Big Four brand name.

Unfortunately, most of the empirical researches in this area have focused only on investigating whether the Big Auditors are better than other auditors (Dopuch and Simunic, 1982; Teoh and Wong, 1993; Francis et al., 1999; Becker et al., 1998).

This research, however, will go a step further to analyze the relationship between client firm characteristics and external auditor choice using a sample of Egyptian listed companies. The Client firms' characteristics that affect the auditor selection and which will be examined in this research are firms' size, profitability, ownership structure, leverage, age, and the existence of a foreign member in the board of directors. This research classifies the audit firm into three categories; Big Four category which includes local audit firms allied to one of the Big Four audit firms, Tier Two category which includes 
local audit firms allied to an International audit firms, and the third category is a local audit firms. The research will first examine the effect of client firms' characteristics on the selection of big four audit firms versus the non- big four audit firms. After that, the research will classify the non- big four audit firms into tier two and local audit firms. Then, the research will examine the effect of the firms' characteristics on the three categories of audit firms, after classifying the non- big four into tier two and local firms versus a big four audit firms. This is to examine whether the second tier international audit firms are distinguished from local audit firms and from the Big-Four in Egypt and to ensure a better understanding of the determinants of external auditor selection.

\section{4- Research hypotheses:}

\section{1-Size:}

In literature, the relationship between client firm size and the demand for higher quality audits has been hypothesized and tested by many researchers (Healy and Lys1986, Johnson and Lys 1990, Simunic and Stein 1987, Firth and Smith 1992, and Abbott and Parker 2000). Citron and Manalis (2001) find that client size is positively related with selection of Big audit firms in Greece. Besides, larger clients may receive more attention from large audit firms (Berton, 1995). Similarly, larger clients may be less satisfied with small audit firms' services. Also the bigger clients may require additional 
professional services such as consultation, tax and legal services, etc. which are more likely to be supplied by larger audit firms.

Based on the above, it can be hypothesized that there is a positive association between client firms' size and selection of higher-quality auditor, accordingly the first hypothesis will be as follows:

$\mathrm{H}_{1}$ : There is a positive association between company size and selection of the Audit Firm.

\section{2-Profitability:}

Previous researches suggest that the profitability of the firms will affect the firm's choice of its audit firm. This is because a more profitable firm is more likely to pay the fee premium demanded by a specialist as a big audit firm (Abbott and Parker, 2000). Johnson and Lys (1990) identify that profitability is a variable that may affect the auditor choice. Consistent with this argument, Abbott and Parker (2000) hypothesize that ROA is positively related to engagement of an industry specialist auditor. They actually find a positive, but not significant, correlation between ROA and industry specialist auditors. Citron and Manalis (2001), however, did not observe a significant difference between the ROA levels of two clients of the two groups of auditors- the Big-Six vs. the non-Big-Six- in the Greek market. They also find that the Big- Six clients are more profitable compared to those of second tier audit firms. Accordingly, a positive association is 
expected between return on assets and selection of higher quality audit firms.

In this research, our profitability measure will be the return on assets, return on equity, and earnings per share. ROA is an indicator of how profitable a company is relative to its total assets. It gives an idea about how efficient management is at using its assets to generate income regardless of how these assets are financed. In addition, ROE reveals how much profit a company generates with the money shareholders have invested in it. Besides, EPS serves as an indicator of a company's profitability by indicating the portion of a company's profit allocated to each outstanding share of common stock.

Based on the above discussion, this research tests the following hypotheses:

$\mathrm{H}_{\mathrm{r}}$ : There is a positive association between company return on assets ratio and the selection of the Audit Firm.

$\mathrm{H}_{r}$ : There is a positive association between company earnings per share and the selection of the Audit Firm.

\section{3-Ownership:}

With respect to the firm's ownership structure, this research is concerned with two points regarding the effect of ownership on the auditor selection, which are the concentration of ownership by large shareholders as well as the percentage of foreign shareholdings. 


\subsection{1- Level of ownership concentration:}

There are two controversial points of view regarding the effect of concentrated ownership on the auditor choice. According to the first point of view, some scholars argue that in firms with high ownership concentration, the internal monitoring is stronger. Large shareholders in these companies have strong incentives to monitor and discipline management to maximize their own benefits. Therefore, according to Thornton and Moore (1993) the incentives to hire a Big Four auditor in these firms with high ownership concentration are lower. In addition, the firms' financial reporting is likely to be opaque due to the incentives for large shareholder to maximize their private benefits through expropriation of other shareholders (LaPorta, et al., 2002; Anderson et al., 2004). Lin and Liu (2009) find that Chinese listed firms with larger controlling shareholders are less likely to hire highquality auditors from 2001 to 2004.

According to the second point of view, scholars argue that firms with controlling shareholders suffer from agency conflict and thus are more likely to hire a Big 4 auditor to mitigate this conflict (Fan \& Wong, 2005). Also, those large shareholders may have an incentive to hire high-quality auditors for the protection of their own interests as well as that of other shareholders. Therefore, the largest shareholders are assumed to prefer high-quality auditors for the protection of their own interests. 
In light of the above arguments, the researcher agrees with the second point of view that firms with higher degree of ownership concentration are more likely to demand high-quality auditors to protect their own interests. Accordingly, the research hypothesis will be as follow:

$\mathrm{H}_{4}$ : There is a positive association between company's percentages of shares held by large shareholders and the selection of the Audit Firm.

\subsection{2- Foreign shareholdings:}

An important matter for companies looking for foreign finance is to hire an international audit firm, since these audit firms are accustomed to the foreign accounting systems as the International Accounting Standards. In addition, these international audit firms will be reliable and will add more credibility to the financial statements of their clients for the users of this information (Citron and Manalis, 2001). Also, multinational firms demand international audit firms because of the lack of harmonization of accounting principles across the global. Moreover, the accounting standards vary among countries and therefore the presence of international audit firms provide a certain type of assurance that is comparable across geographical boundaries (Aksu et al., 2007). By contrast, public sector companies will demand a public audit firm and seldom choose a big four audit firm. 
In light of the above, we expect that the level of foreign shareholdings is positively associated with the choice of a Big-Four auditor. Accordingly, the sixth hypothesis will be as follows:

$\mathrm{H}_{5}$ : There is a positive association between the percentage of foreign shareholdings in a company and the selection of the Audit Firm.

\section{4- Leverage:}

Actually, many researchers have examined the relationship between the client firm size and the selection of a Big audit firm (Einchenseher and Shields, 1989; DeFond, 1992; and Firth and Smith, 1992). Einchenseher and Shields (1989), DeFond (1992), Firth and Smith (1992) find a positive relationship between leverage and demand for higher brand name reputation auditors. Johnson and Lys (1990) interpret the positive association as the large audit firms' ability to diversify away the risk associated with high leverage. However, Fransic and Wilson (1988) find a negative relationship between leverage and brand name auditors. In support of the negative relation, Healy and Lys (1986) and Johnson and Lys (1990) find that firms with higher debt levels are more likely to switch to a lower quality auditor.

From the demand side, risky client firms with highly leveraged would look for a lenient auditor to get a clean opinion even though the firm might not be a going-concern. On the supply side however, 
leverage is a factor that increases the audit risk and thus affects the Big Audit firms' willingness to be the auditor of such a financially distressed client. In fact, higher quality, brand name auditors are not willing to accept clients with higher audit risks. In this research, we expect that leverage to be negatively correlated with the selection of higher-quality auditors. Accordingly, the research hypothesis will be as follows:

$\mathrm{H}_{6}$ : There is a negative association between company leverage and the selection of the Audit Firm.

\section{5- Firm's Age:}

In reality, older firms are more likely to exist in more mature industries. These firms are more profitable and bigger in size. In fact, older firm would have to deal with accounting problems relating to earlier periods. With the increase in age accounting becomes more complex. So, older firms may require high qualified professional auditors. Hence these companies will demand a big four audit firm. Besides, mature firms already have stable performance and cash flows and stronger reputation which these firms aim to maintain. Accordingly, mature firms will look for a high quality audit firm.

On the contrary, younger firms are smaller in size. Also, these firms are less profitable and will take a period of time to show profitability. In addition, these firms have high uncertainty about its future cash flows and have a high probability of being delisted in their 
early years. Accordingly, the demand of these firms to get a high quality audit firm will be low. However, some new firms may also have incentives enhance its reputation by selecting a big audit firm.

In this research, we agree with the first point of view that mature firms will be more likely to select a big audit firm. Accordingly, the next hypothesis will be as follow:

$\mathrm{H}_{7}$ : There is a positive association between company's age and the selection of the Audit Firm.

\section{6- Foreign members in the board of directors:}

The board of directors has the ultimate responsibility for the implementation of corporate governance in a company. According to Fama (1980) and Fama and Jensen (1983) boards of directors are used as a mechanism to control the conflict between the owners and the managers as they perform a monitoring role. Actually, the board of directors is an important mechanism to constrain managers' opportunistic behavior. In previous literature, the choice regarding the board composition comprises an important governance mechanism (Ahmed \& Duellman, 2007; Dechow et al., 2010).

Actually, the inclusion of a foreign board member is a step forward in a firm's globalization process and reflects the fact that these companies have successfully develop their domestic corporate governance by importing a foreign corporate governance system. The existence of a foreign board members in the board of directors help 
directors to stress openness and frankness in performing their monitoring tasks, rather than giving priority to respect and politeness among the board members (Oxelheim \& Randøy, 2003). Foreign directors will be more willing to provide the stakeholders with qualitative and correct information, therefore increasing the quality of their monitoring role. Foreign directors have a positive influence on the reduction of management fraud (Hooghiemstra et al. 2015). In addition, as these directors come from outside they will exercise independent thinking and will be less reluctant to raise controversial issues. This will benefit discussions within the boardroom and contribute to increased monitoring effectiveness (Srinidhi et al., 2011). Indeed, foreign directors may bring different viewpoints to the boardroom given their different backgrounds and experiences. Again, this may raise the effectiveness of boards when it comes to carrying out their monitoring task.

In fact, different nationality means different cultural values and different management practices. No distinction is made between one or more foreign board members since already one foreign board member achieves the required effect. Actually, these differences can increase the governance standards of these firms that would lead to a positive relation between foreign board membership and the selection of a big audit firm. Besides, the existence of a foreign board member will promote the exchange of information by disseminating information to their international network. Accordingly all of these will increase the demand for an international audit firm. This 
international audit firm can be described as a solution for the lack of global harmonization of accounting principles.

In this research, we focus on how the internationalization of a corporate board by hiring a foreign board member can affect the selection of a Big Audit firm to ensure a high quality audit of their financial statements. We suggest that there the existence of a foreign member will be positively correlated with the selection of higherquality auditors. Accordingly, the research hypothesis will be as follow:

$\mathrm{H}_{8}$ : the presence of a foreign board member has a positive impact on the selection of the Audit Firm.

The research begins by testing the above hypotheses related to the impact of clients' characteristics on the selection of a Big Four Audit Firm versus a non Big Four Audit Firm. After that, the research tests the same above hypotheses related to the selection of a Tier two Auditor versus a local Auditor. The main aim of examining the two sets of hypotheses is to examine whether the Big-Four Audit Firm are distinguished from Tier two Audit Firms and from Local audit firms. As well as, to examine whether the second tier international audit firms are distinguished from the local Auditors in Egypt. As well as ensuring a better understanding of the determinants of external Auditor selection in case of Egypt. 


\section{5-The Design of the Empirical Study:}

\subsection{Research population:}

The population of this research consists of all firms listed in the Egyptian Capital Market in the year 2013. The number of these firms is 212 firms listed in the Egyptian Stock of Exchange. These firms are divided into 17 sectors. This information as of mentioned in the web site of the Egyptian Stock of Exchange for the year 2013.

\subsection{Research Sample:}

The research sample consists of 101 firms listed in the Egyptian Capital Market after excluding firms which prepare its financial statements in a foreign currency. In addition, the research sample also excludes banks and other firms operating in the financial services. Actually, banks and other financial institutions constitute a distinct industry. The accounting procedures are quite different in the financial sector. Besides, financial service firms operate under strict regulatory constraints on how they run their businesses and how much capital they need to set aside to be able to continue operating. In addition, banks have several branches connected to one another through networks that necessitate special audit expertise and technical competence, which only the big audit companies can provide. Accordingly, banks and other firms in the financial sector are excluded because of the different nature of this sector. The firms 
included in the research sample as divided into sectors are indicated in table (1) as follows:

Table (1): Firms included in the Research Sample by

\section{Sector:}

\begin{tabular}{|c|c|c|c|}
\hline Sector & $\begin{array}{c}\text { Number of firms } \\
\text { in this sector }\end{array}$ & $\begin{array}{c}\text { Number of firms } \\
\text { in the sample }\end{array}$ & $\begin{array}{l}\text { The percent of each } \\
\text { sector in the sample }\end{array}$ \\
\hline Food and Beverage & 26 & 23 & $22.8 \%$ \\
\hline $\begin{array}{l}\text { Healthcare and } \\
\text { Pharmaceuticals }\end{array}$ & 16 & 11 & $10.9 \%$ \\
\hline $\begin{array}{l}\text { Industrial Goods and } \\
\text { Services and Automobiles }\end{array}$ & 11 & 6 & $5.9 \%$ \\
\hline Oil and Gas & 2 & 2 & $1.98 \%$ \\
\hline $\begin{array}{l}\text { Personal and Household } \\
\text { Products }\end{array}$ & 8 & 3 & $2.97 \%$ \\
\hline Real Estate & 28 & 15 & $14.85 \%$ \\
\hline Retail & 3 & 3 & $2.98 \%$ \\
\hline Media & 1 & 1 & $.9 \%$ \\
\hline Technology & 3 & 3 & $2.98 \%$ \\
\hline Travel \& Leisure & 12 & 8 & $7.9 \%$ \\
\hline Utilities & 1 & 1 & $.9 \%$ \\
\hline Basic Resources & 8 & 6 & $5.9 \%$ \\
\hline Chemicals & 7 & 3 & $2.98 \%$ \\
\hline $\begin{array}{l}\text { Construction and } \\
\text { Materials }\end{array}$ & 21 & 14 & $13.9 \%$ \\
\hline Total & 147 & 101 & $100 \%$ \\
\hline
\end{tabular}

\subsection{Data collection method:}

The researcher gathered the information from the web site of the Egyptian Stock of Exchange as well as from the annual financial reports of the listed firms for the year 2013. 


\subsection{Statistical methods used in the analysis of data:}

The data of this research is undergone for statistical analysis in order to check the validity of the hypotheses. The researcher used the SPSS program to provide the statistical indicators. The decision of accepting or rejecting of these hypotheses depends on the observed level of significance. Data were analyzed on the assumption that the level of significance equal to $1 \%$, it is meaning that the maximum acceptance probability of falling into the error is 0.01 . The Statistical methods used in the analysis of data are as follows:

5.4.1-The point-biserial correlation coefficient: In statistics, the point-biserial correlation coefficient is a correlation coefficient used when the dependent variable is nominal or dichotomous variable while the other independent variables are continuous variables. In fact, the point-biserial correlation is mathematically equivalent to the Pearson correlation, that it is a special case of the Pearson correlation. Accordingly, a Pearson correlation was used to examine the correlation between the dependent variable the selection of a Big Four and each of the independent variables used in this research.

5.4.2-The Phi coefficient and Cramer's V: In statistics, the phi coefficient is a measure of association for two binary variables; and the Cramér's V is a measure of association between two nominal variables, giving a value between 0 and 1 . This research used the Phi coefficient and Cramer's V as nominal association measures of the association between two binary nominal variables. 
These coefficients are used to examine the correlation between the audit firm and the dummy independent variables as the membership in the financial sector and the existence of a foreign member in the board of directors.

5.4.3-Binary logistic regression: In statistics, the Binary logistic regression is a regression model where the dependent variable is categorical binary dependent variable that takes only two values. This research used the binary logistic regression to test whether the specified independent variables contribute significantly to the prediction of the selection of the Audit Firm. As indicated in the correlation analysis, the correlation matrix revealed that the problem of Multicollinearity existed between the independent variables, which means that two or more of the independent variables in a multiple regression model are highly correlated. Accordingly, the Binary logistic regression is used to test the relationship between the selection of the audit firm and each of the explanatory variables separately.

5.4.4-Multinomial logistic regression: In statistics, the Multinomial logistic regression is a model that is used to predict the probabilities of the possible outcomes of a categorically distributed dependent variable, given a set of independent variables. It is used when the dependent variable is nominal and falls into more than two categories. This research also used the Multinomial logistic regression to test the effect of client firm's characteristics on the selected Auditor as classified into a Big Four, a Tier two, and a local audit firm. As 
indicated in the correlation analysis, the correlation matrix revealed that the problem of Multicollinearity existed between the independent variables, which means that two or more of the independent variables in a multiple regression model are highly correlated. Accordingly, the Multinomial logistic regression is used to test the relationship between the selection of the audit firm and each of the explanatory variables separately.

\subsection{Measurement of Research Variables:}

With respect to the independent variables, the independent variables are a set of client firms' characteristics which are described as follows:

1. Size: is measured by taking the natural logarithm of total assets.

2. Return on assets: is measured by dividing a company's annual earnings by its total assets $=$ Net income/ total assets

3. Return on equity: is measured by dividing a company's annual earnings by its total assets $=$ Net income/ shareholders' equity.

4. Earnings per share: is measured by dividing a company's annual earnings by the number of outstanding shares $=$ Net income $/$ number of outstanding shares.

5. The financial leverage: is measured by dividing both short-term and long-term debts by total equity.

6. Ownership concentration: is measured by the percentage of shares held by the largest shareholders. 
7. Foreign shareholdings: is measured by the percentage of shares held by foreign shareholders.

8. Firm age: is measured by the number of years since the firm is listed on the Egyptian Stock of Exchange.

9. Foreign board member: equals 1 if there is a foreign member in the board, or equal to 0 otherwise.

With respect to the dependent variable, the dependent variable is the selection of the Audit Firm. The Audit Firms may be a Big Four Audit Firms which includes local audit firms affiliated to one of the Big Four audit firms, or a non Big Four. The non Big Four may be a Tier Two Audit Firms which includes local audit firms affiliated to an International audit firms, or a local Audit Firms.

A)- In the First Binary logistic regression: The Audit Firm will be measured as follows:

Audit Firm $=1$, if the auditor is a Big Four Audit Firms or $=0$ if auditor is Non- Big Audit Firm.

B)- In the second Binary logistic regression: The Audit Firm will be measured as follows:

Audit Firm = 1, if the auditor is a Tier Two Audit Firms

or $=0$ if auditor is a Local Auditors. 


\section{Research Results:}

\section{1-Descriptive statistics:}

First, the descriptive statistics were conducted for the explanatory variables. Table (2) provides the descriptive analysis which includes the mean and the standard deviation for the explanatory variables.

Table (2): Descriptive Statistics of the Explanatory variables

\begin{tabular}{|l|c|c|c|c|c|}
\hline & $\mathrm{N}$ & Minimum & Maximum & Mean & $\begin{array}{c}\text { Std. } \\
\text { Deviation }\end{array}$ \\
\hline Size & 101 & 16.99 & 22.67 & 19.6828 & 1.33914 \\
ROA & 101 & -.77 & .93 & .0601 & .15517 \\
EPS & 101 & -10.09 & 11.61 & 1.3392 & 2.92332 \\
Ownership & 101 & .00 & 1.00 & .4509 & .26368 \\
concentration & 101 & .00 & .91 & .1075 & .21648 \\
Foreign shareholdings & 101 & .00 & 34.45 & 2.0780 & 5.26509 \\
Leverage & 101 & 1.00 & 31.00 & 14.4851 & 6.27951 \\
Listed Age & 101 & & & & \\
Valid N (listwise) & & & & & \\
\hline
\end{tabular}

Second, the frequencies of the dummy variables are presented. Table (3) presents the frequency of the big four which indicates that only 20 firms which represent about $20 \%$ of the firms are audited by a Big Four audit firm, while 51 firms which represent about $51 \%$ of the firms are audited by a local audit firm, and 30 firms which represent about $30 \%$ of the firms are audited by an audit firm with a foreign auditor. 
Table (3): Frequency of Audit Firm

\begin{tabular}{|l|c|c|c|c|}
\hline & Frequency & Percent & $\begin{array}{c}\text { Valid } \\
\text { Percent }\end{array}$ & $\begin{array}{c}\text { Cumulative } \\
\text { Percent }\end{array}$ \\
\hline $\begin{array}{l}\text { Valid Local Auditor } \\
.00\end{array}$ & 51 & 50.5 & 50.5 & 50.5 \\
$\begin{array}{l}\text { Local with a } \\
\text { Foreign 1.00 } \\
\text { Big Four }\end{array}$ & 30 & 29.7 & 29.7 & 80.2 \\
$\begin{array}{l}\text { 2.00 } \\
\text { Total }\end{array}$ & 101 & 10.8 & 19.8 & 100.0 \\
\hline
\end{tabular}

Table (4) presents the frequency of the existence of a foreign member in the board of directors which indicates that 19 firms which represent about $20 \%$ of the firms have a foreign board member, while 82 firms which represent about $81 \%$ of the firms do not have a foreign member in their board of directors.

Table (4): Frequency of Foreign board Member

\begin{tabular}{|l|c|c|c|c|}
\hline & Frequency & Percent & $\begin{array}{c}\text { Valid } \\
\text { Percent }\end{array}$ & $\begin{array}{c}\text { Cumulative } \\
\text { Percent }\end{array}$ \\
\hline $\begin{array}{l}\text { Valid Non- existence } \\
.00\end{array}$ & 82 & 81.2 & 81.2 & 81.2 \\
$\begin{array}{l}\text { Existence } \\
1.00\end{array}$ & 19 & 18.8 & 18.8 & 100.0 \\
Total & 101 & 100.0 & 100.0 & \\
\hline
\end{tabular}

\section{2- Empirical results of the impact of clients' firm characteristics}

\section{on the Selection of a Big Four Audit Firm:}

\subsubsection{Correlation Analysis:}

In this research, The Correlation Analysis including the Pearson correlation, the Phi coefficient, and Cramer's V are used to 
assess the correlation between the selection of the Audit Firm and the characteristics of the client firms. The results of the correlation analysis are as follows:

The Pearson Correlation Matrix for the selection of a Big Four audit firm and the independent variables are presented in Tables (5) below. The statistical results show that significant positive relationships were found between the selection of a Big Four and the firm's size $(r=.379)$, ReturnOn-Assets $(\mathrm{r}=.279)$, EPS $(\mathrm{r}=.326)$, and foreign shareholdings variables $(\mathrm{r}$ $=.406)$ at the $\mathrm{P}<0.01$ level. According, these results support hypotheses $\mathrm{H}_{1}$, which states that there is a significant positive relationship between firm's size and the selection of a Big Four, and $\mathrm{H}_{2}$, which states that there is a significant positive relationship between firm's return on assets and the selection of a Big Four auditor. Besides, the results also support $\mathrm{H}_{3}$ which states that there is a significant positive relationship between firm's earnings per share and the selection of a Big Four auditor. In addition, the results do support $\mathrm{H}_{6}$ which states that there is a significant positive relationship between the foreign shareholdings and the selection of a Big Four. Accordingly, the results do support hypotheses $\mathrm{H}_{1}, \mathrm{H}_{2}, \mathrm{H}_{3}$, and $\mathrm{H}_{5}$.

However, no significant correlation was found between the selection of a Big Four and other firms characteristics. No other statistically significant correlations were found. Ownership concentration ( $\mathrm{r}=.028, \mathrm{p}=.783)$, leverage $(\mathrm{r}=-.108, \mathrm{p}=.282)$, and firm's age $(\mathrm{r}=-.007, \mathrm{p}=.946)$. The results of the leverage variable were to be found negative as expected but it was found to be non- significantly correlated. Accordingly, these results do not appear to support hypotheses $\mathrm{H}_{4}, \mathrm{H}_{6}, \mathrm{H}_{7}$, and $\mathrm{H}_{8}$. 
In addition, the correlation matrix revealed that the problem of Multicollinearity existed between the independent variables. In statistics, Multicollinearity is a phenomenon in which two or more predictor variables in a multiple regression model are highly correlated.

Tables (5): The Pearson Correlation Matrix of a Big Four audit firm and the client's characteristics:

\begin{tabular}{|c|c|c|c|c|c|c|c|c|c|}
\hline & & Big & Size & ROA & EPS & $\begin{array}{l}\text { Ownership } \\
\text { concentrat }\end{array}$ & $\begin{array}{l}\text { Foreign } \\
\text { holdings }\end{array}$ & Leverage & Age \\
\hline \multirow[t]{3}{*}{ Big } & $\begin{array}{l}\text { Pearson } \\
\text { Correlation }\end{array}$ & 1 & $.379^{* * *}$ & $.279^{* * *}$ & $.326^{* *}$ & .028 & $.406^{* *}$ & -.108 & -.007 \\
\hline & $\begin{array}{l}\text { Sig. (2- } \\
\text { tailed) }\end{array}$ & & .000 & .005 & .001 & .783 & .000 & .282 & .946 \\
\hline & $\mathbf{N}$ & 101 & 101 & 101 & 101 & 101 & 101 & 101 & 101 \\
\hline \multirow[t]{5}{*}{ Size } & Pearson & $.379^{* *}$ & 1 & $.231^{*}$ & .131 & $.371^{* *}$ & .078 & .012 & $.205^{*}$ \\
\hline & Correlation & & & & & & & & \\
\hline & Sig. (2- & .000 & & .020 & .191 & .000 & .438 & .904 & .039 \\
\hline & tailed) & & & & & & & & \\
\hline & $\mathbf{N}$ & 101 & 101 & 101 & 101 & 101 & 101 & 101 & 101 \\
\hline \multirow[t]{5}{*}{ ROA } & Pearson & $.279^{* *}$ & $.231^{*}$ & 1 & $.452^{* *}$ & .014 & .169 & $-.307^{* *}$ & -.025 \\
\hline & Correlation & & & & & & & & \\
\hline & Sig. (2- & .005 & .020 & & .000 & .892 & .091 & .002 & .802 \\
\hline & tailed) & & & & & & & & \\
\hline & $\mathbf{N}$ & 101 & 101 & 101 & 101 & 101 & 101 & 101 & 101 \\
\hline \multirow[t]{5}{*}{ EPS } & Pearson & $.326^{* *}$ & .131 & $.452^{* * *}$ & 1 & -.194 & $.247^{*}$ & $-.351^{* *}$ & .095 \\
\hline & Correlation & & & & & & & & \\
\hline & Sig. (2- & .001 & .191 & .000 & & .052 & .013 & .000 & .345 \\
\hline & tailed) & & & & & & & & \\
\hline & $\mathbf{N}$ & 101 & 101 & 101 & 101 & 101 & 101 & 101 & 101 \\
\hline
\end{tabular}




\begin{tabular}{|c|c|c|c|c|c|c|c|c|c|}
\hline $\begin{array}{l}\text { Ownership } \\
\text { Concentrate }\end{array}$ & $\begin{array}{l}\text { Pearson } \\
\text { Correlation } \\
\text { Sig. (2- } \\
\text { tailed) } \\
\mathrm{N} \\
\end{array}$ & $\begin{array}{r}.028 \\
\\
.783 \\
\\
\\
101 \\
\end{array}$ & $\begin{array}{l}.371^{* *} \\
.000 \\
101 \\
\end{array}$ & $\begin{array}{r}.014 \\
.892 \\
101 \\
\end{array}$ & $\begin{array}{r}-.194 \\
\\
.052 \\
\\
101 \\
\end{array}$ & 101 & $\begin{array}{r}-.114 \\
.258 \\
\\
101 \\
\end{array}$ & $\begin{array}{l}.292^{* *} \\
.003 \\
\\
101 \\
\end{array}$ & $\begin{array}{r}.243^{*} \\
.014 \\
.101 \\
\end{array}$ \\
\hline $\begin{array}{l}\text { Foreign } \\
\text { holdings }\end{array}$ & $\begin{array}{l}\text { Pearson } \\
\text { Correlation } \\
\text { Sig. (2- } \\
\text { tailed) } \\
\mathrm{N} \\
\end{array}$ & $\begin{array}{l}.406^{* *} \\
.000 \\
101 \\
\end{array}$ & $\begin{array}{l}.078 \\
\\
.438\end{array}$ & $\begin{array}{l}.169 \\
.091 \\
\\
101 \\
\end{array}$ & $\begin{array}{l}.247^{*} \\
.013 \\
\\
101 \\
\end{array}$ & $\begin{array}{l}-.114 \\
.258 \\
\\
101 \\
\end{array}$ & 101 & $\begin{array}{r}.172 \\
101 \\
\end{array}$ & .074 \\
\hline Leverage & $\begin{array}{l}\text { Pearson } \\
\text { Correlation } \\
\text { Sig. (2- } \\
\text { tailed) } \\
\mathrm{N} \\
\end{array}$ & $\begin{array}{r}-.108 \\
.282 \\
\\
101 \\
\end{array}$ & $\begin{array}{l}.012 \\
.904 \\
\\
101 \\
\end{array}$ & $\begin{array}{c}-.307^{* *} \\
.002 \\
\\
101 \\
\end{array}$ & $\begin{array}{c}-.351^{* *} \\
.000 \\
101 \\
\end{array}$ & $\begin{array}{l}.292^{* *} \\
.003 \\
\\
101 \\
\end{array}$ & $\begin{array}{l}-.137 \\
.172 \\
101 \\
\end{array}$ & 101 & $\begin{array}{r}.121 \\
101 \\
\end{array}$ \\
\hline Age & $\begin{array}{l}\text { Pearson } \\
\text { Correlation } \\
\text { Sig. (2- } \\
\text { tailed) } \\
\mathrm{N}\end{array}$ & $\begin{array}{l}-.007 \\
\\
.946 \\
\\
101 \\
\end{array}$ & $\begin{array}{l}.205^{*} \\
.039 \\
\\
.01 \\
\end{array}$ & $\begin{array}{l}-.025 \\
.802 \\
\\
101 \\
\end{array}$ & $\begin{array}{l}.095 \\
.345 \\
\\
.101 \\
\end{array}$ & $\begin{array}{l}.243^{*} \\
.014 \\
\\
.101 \\
\end{array}$ & $\begin{array}{r}.074 \\
\\
.461 \\
101 \\
\end{array}$ & .121 & 101 \\
\hline
\end{tabular}

**. Correlation is significant at the 0.01 level (2-tailed).

*. Correlation is significant at the 0.05 level (2-tailed).

The Phi coefficient and Cramer's V are used to test the correlation between the existence of a foreign board member and the selection of a Big Four audit firm. The results (the value $=.481, \mathrm{p}=.000$ ) support the hypothesis that there is a significant relationship between the existence of a foreign board member and the selection of a big four. Accordingly, these results do support hypothesis $\mathrm{H}_{8}$. 


\subsection{2-Logistic Regression Analysis:}

The results of running the Binary logistic regressions of a Big Four versus non- Big Four Auditor Selection using the SPSS are presented in Tables (6).

Table (6): Summary of the Binary logistic regression of client's characteristics impact on the selection of Big Four versus non- Big Four Audit Firm:

\begin{tabular}{|l|c|c|c|c|c|}
\hline \multicolumn{1}{|c|}{ Variable } & $\begin{array}{c}\text { Expected } \\
\text { sign }\end{array}$ & $\begin{array}{c}\text { Coeff. } \\
\mathrm{B}\end{array}$ & Sig. & $\operatorname{Exp}(\mathrm{B})$ & $\begin{array}{c}\text { Nagelkerke R } \\
\text { Square }\end{array}$ \\
\hline Size & + & .833 & .001 & 2.299 & .226 \\
\hline ROA & + & 6.272 & .018 & 529.282 & .133 \\
\hline EPS & + & .288 & .002 & 1.333 & .159 \\
\hline Ownership & + & .264 & .780 & 1.302 & .001 \\
\hline $\begin{array}{l}\text { foreign } \\
\text { holdings }\end{array}$ & + & 3.864 & .000 & 47.666 & .202 \\
\hline Leverage & - & -.158 & .354 & .853 & .033 \\
\hline Age & + & -.003 & .946 & .997 & .000 \\
\hline Foreign board & + & 2.412 & .000 & 11.153 & .258 \\
\hline
\end{tabular}

Table (6) shows that the size variable was significant ( $r=2.299$, $\operatorname{sig}=.001)$ and the model coefficient was significant at $1 \%$ significance level and the Nagelkerke R Square was .226. Accordingly the first hypothesis is supported; there is a statistically significant positive relationship between the firm's size and a Big Four selection. In addition, the results show that the ROA variable was significant ( $r=$ 529.282, sig=.018) at .01 significance level and the Nagelkerke R Square was .133. Accordingly the second hypothesis is supported; there is a statistically significant positive relationship between the 
firms' ROA and a Big Four selection. Besides, the EPS variable was significant ( $\mathrm{r}=1.333$, sig=.002) at .01 significance level and the Nagelkerke R Square was .159. Accordingly the third hypothesis is supported; there is a statistically significant positive relationship between the firms' EPS and a Big Four selection. Besides, results also show that the foreign shareholdings variable was significant ( $\mathrm{r}=47.666$, sig=.000) and the Nagelkerke R Square was .202, accordingly the fifth hypothesis is supported, there is a statistically significant positive relationship between foreign shareholdings and a Big Four selection. In addition, results also show that the existence of foreign members was significant $(\mathrm{r}=11.153$, $\mathrm{sig}=.000)$ and the Nagelkerke R Square was .258. Accordingly the eighth hypothesis is supported; there is a statistically significant positive relationship between the presence of a foreign board member and a Big Four selection.

However, Results show that the ownership concentration variable was insignificant $(\operatorname{sig}=.780)$ at 1 percent significance level and accordingly the fourth hypothesis is rejected. There is no statistically significant relationship between ownership concentration and a Big Four selection. In addition, results found that the coefficient of the leverage variable was negative as expected however it was insignificant at .01 significance level $(\mathrm{B}=-.158, \mathrm{sig}=.354)$. Accordingly the sixth hypothesis is rejected. This means that there is a negative but non- significant relationship between leverage and a Big Four selection. In addition, results also shows that the age variable was 
insignificant at .01 significance level (sig=.946). Accordingly the seventh hypothesis is rejected. There is no statistically significant relationship between Age and a Big Four selection.

\section{3- Empirical results of the impact of clients' firm characteristics on the Selection of a Tier Two Audit Firm:}

\subsubsection{Correlation Analysis:}

The Pearson Correlation Matrix for Tier Two Audit Firm selection and clients' characteristics are presented in Table (7) below. The statistical results show that significant positive relationships were found between the selection of a Tier two and the firm's size ( $r=$ .249), Return-On-Assets $(\mathrm{r}=.205)$, EPS $(\mathrm{r}=.210)$, and foreign shareholdings variables $(\mathrm{r}=.386)$ at the $\mathrm{P}<0.01$ level. According, these results support hypotheses $\mathrm{H}_{1}$, which states that there is a significant positive relationship between firm's size and the selection of the Tier two Auditors, and $\mathrm{H}_{2}$, which states that there is a significant positive relationship between firm's return on assets and the selection of Tier two Auditors. Besides, the results also support $\mathrm{H}_{3}$ which states that there is a significant positive relationship between firm's earnings per share and the selection of Tier two Auditors. In addition, the results do support $\mathrm{H}_{6}$ which states that there is a significant positive relationship between the foreign shareholdings and the selection of the Tier two Auditors. Accordingly, the results do support hypotheses $\mathrm{H}_{1}, \mathrm{H}_{2}, \mathrm{H}_{3}$, and $\mathrm{H}_{5}$. 
However, no significant correlation was found between the selection of Tier two Auditors and other firms' characteristics. No other statistically significant correlations were found. Ownership concentration ( $\mathrm{r}=-.076, \mathrm{p}=.448)$, leverage $(\mathrm{r}=-.092, \mathrm{p}=.361)$, and firm's age $(\mathrm{r}=.021, \mathrm{p}=.832)$. Although, the results of the leverage variable were to be found negative as expected but it was found to be non- significantly correlated. Accordingly, these results do not appear to support hypotheses $\mathrm{H}_{4}, \mathrm{H}_{6}, \mathrm{H}_{7}$, and $\mathrm{H}_{8}$.

In addition, the correlation matrix revealed that the problem of Multicollinearity existed between the independent variables.

Tables (7): The Pearson Correlation Matrix of a Tier Two audit firm and the client's characteristics:

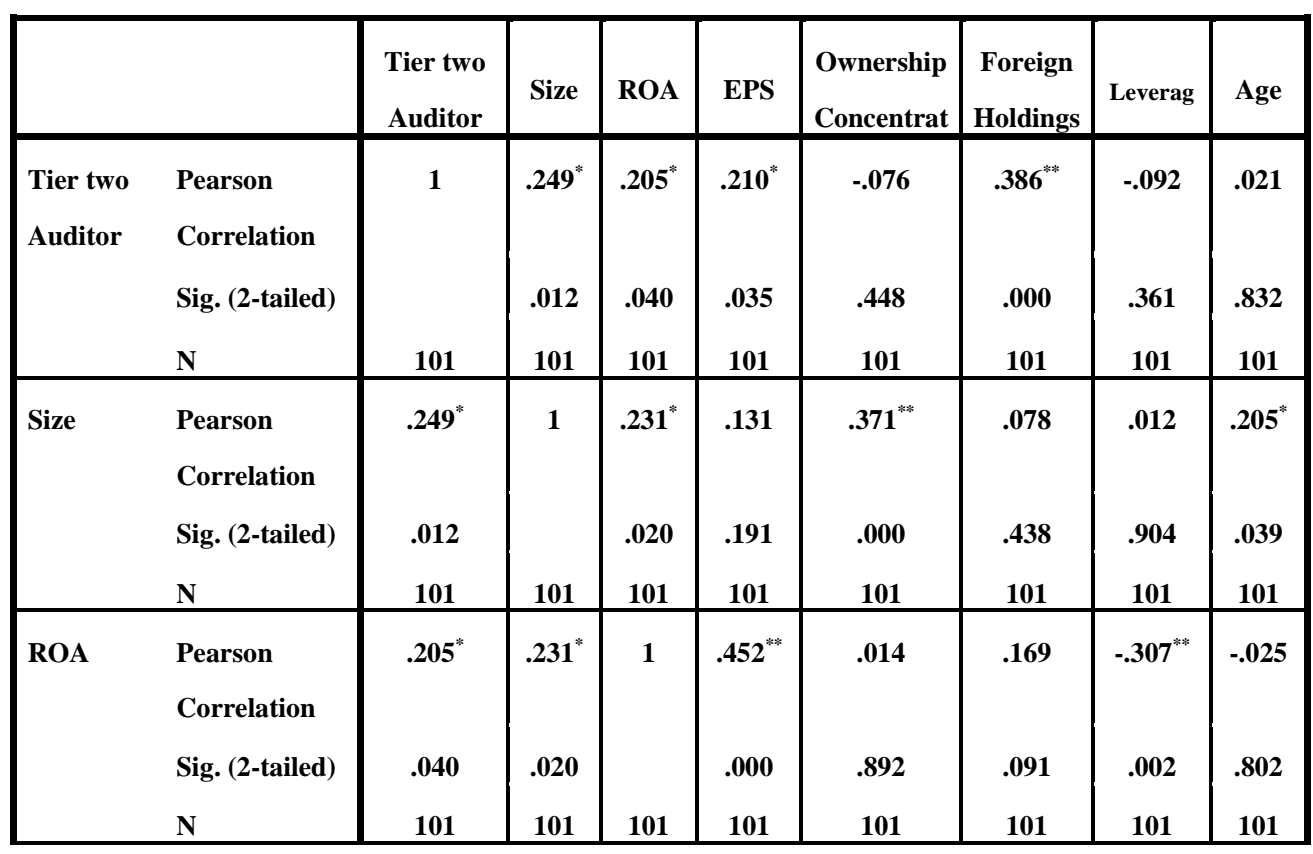




\begin{tabular}{|c|c|c|c|c|c|c|c|c|c|}
\hline EPS & $\begin{array}{l}\text { Pearson } \\
\text { Correlation } \\
\text { Sig. (2-tailed) } \\
\mathbf{N} \\
\end{array}$ & $\begin{array}{l}.210^{*} \\
\\
.035 \\
101 \\
\end{array}$ & $\begin{array}{r}.191 \\
101 \\
\end{array}$ & $\begin{array}{l}.452^{* *} \\
.000 \\
101 \\
\end{array}$ & 101 & $\begin{array}{l}-.194 \\
\\
.052 \\
101 \\
\end{array}$ & $\begin{array}{r}.247^{*} \\
\\
.013 \\
101\end{array}$ & $\begin{array}{c}-.351^{* *} \\
.000 \\
101 \\
\end{array}$ & $\begin{array}{r}.095 \\
\\
.345 \\
.101 \\
\end{array}$ \\
\hline $\begin{array}{l}\text { Ownershi } \\
\text { p }\end{array}$ & $\begin{array}{l}\text { Pearson } \\
\text { Correlation } \\
\text { Sig. (2-tailed) } \\
\text { N }\end{array}$ & $\begin{array}{r}-.076 \\
\\
.448 \\
101 \\
\end{array}$ & $\begin{array}{l}.371^{* *} \\
.000 \\
101 \\
\end{array}$ & $\begin{array}{l}.892 \\
101 \\
\end{array}$ & $\begin{array}{c}-.194 \\
\\
.052 \\
101 \\
\end{array}$ & 101 & $\begin{array}{l}.258 \\
101 \\
\end{array}$ & $\begin{array}{l}.292^{* *} \\
\\
.003 \\
101 \\
\end{array}$ & $\begin{array}{l}.243^{*} \\
\\
.014 \\
101 \\
\end{array}$ \\
\hline $\begin{array}{l}\text { Foreign } \\
\text { Holdings }\end{array}$ & $\begin{array}{l}\text { Pearson } \\
\text { Correlation } \\
\text { Sig. (2-tailed) } \\
\text { N } \\
\end{array}$ & $\begin{array}{l} \\
.000 \\
101 \\
\end{array}$ & $\begin{array}{l}.438 \\
.101 \\
\end{array}$ & $\begin{array}{l}.169 \\
\\
.091 \\
101 \\
\end{array}$ & $\begin{array}{l}.247^{*} \\
\\
.013 \\
101 \\
\end{array}$ & $\begin{array}{l}-.114 \\
\\
.258 \\
101 \\
\end{array}$ & 101 & $\begin{array}{l}-.137 \\
\\
.172 \\
101 \\
\end{array}$ & $\begin{array}{r}.074 \\
\\
.461 \\
101 \\
\end{array}$ \\
\hline Leverage & $\begin{array}{l}\text { Pearson } \\
\text { Correlation } \\
\text { Sig. (2-tailed) } \\
\text { N } \\
\end{array}$ & $\begin{array}{l}.361 \\
.101 \\
\end{array}$ & $\begin{array}{l}.904 \\
101 \\
\end{array}$ & $\begin{array}{c}- \\
.307^{* *} \\
.002 \\
101 \\
\end{array}$ & $\begin{array}{c}-.351^{* *} \\
.000 \\
101 \\
\end{array}$ & $\begin{array}{l}.292^{* *} \\
.003 \\
101 \\
\end{array}$ & $\begin{array}{r}-.137 \\
\\
.172 \\
101 \\
\end{array}$ & 101 & $\begin{array}{l}.155 \\
\\
.121 \\
101 \\
\end{array}$ \\
\hline Age & $\begin{array}{l}\text { Pearson } \\
\text { Correlation } \\
\text { Sig. (2-tailed) } \\
\text { N }\end{array}$ & $\begin{array}{l}.832 \\
101\end{array}$ & $\begin{array}{l}.205^{*} \\
\\
.039 \\
101\end{array}$ & $\begin{array}{l}.802 \\
.01\end{array}$ & $\begin{array}{l}.345 \\
101\end{array}$ & $\begin{array}{l}.014 \\
101\end{array}$ & $\begin{array}{l}.461 \\
101\end{array}$ & $\begin{array}{l}.121 \\
101\end{array}$ & 101 \\
\hline
\end{tabular}

*. Correlation is significant at the 0.05 level (2-tailed).

**. Correlation is significant at the 0.01 level (2-tailed).

The Phi coefficient and Cramer's V are used to test the correlation between the existence of a foreign board member and the selection of a Tier two audit firm. The results (the value $=. r^{4}$, $p=.000$ ) support the hypothesis that there is a significant relationship between the existence of a foreign board member and the selection of a tier two auditor. Accordingly, these results do support hypothesis $\mathrm{H}_{8}$. 


\subsubsection{Logistic Regression Analysis:}

The results of running the Binary logistic regressions of a Tier Two Audit Firm versus A local Auditor Selection using the SPSS are presented in Tables (8) as follows:

Table (8): Summary of the Binary logistic regression of client's characteristics impact on the selection of a Tier Two Audit Firm versus A local Auditor:

\begin{tabular}{|l|c|c|c|c|c|}
\hline Variable & $\begin{array}{c}\text { Expected } \\
\text { sign }\end{array}$ & $\begin{array}{c}\text { Coeff. } \\
\mathrm{B}\end{array}$ & Sig. & $\operatorname{Exp}(\mathrm{B})$ & $\begin{array}{c}\text { Nagelkerke R } \\
\text { Square }\end{array}$ \\
\hline Size & + & .391 & .014 & 1.479 & .082 \\
\hline ROA & + & 3.579 & .061 & 35.829 & .063 \\
\hline EPS & + & .162 & .045 & 1.176 & .061 \\
\hline Ownership & + & -.585 & .444 & .557 & .008 \\
\hline $\begin{array}{l}\text { foreign } \\
\text { holdings }\end{array}$ & + & 5.709 & .002 & 301.602 & .223 \\
\hline Leverage & - & -.038 & .377 & .962 & .012 \\
\hline Age & + & .007 & .830 & 1.007 & .001 \\
\hline Foreign board & + & 2.019 & .003 & 7.529 & .151 \\
\hline
\end{tabular}

Table (8) shows that the size variable was significant ( $r=1.479$, $\operatorname{sig}=.014)$ and the model coefficient was significant at $1 \%$ significance level and the Nagelkerke R Square was .082. Accordingly the first hypothesis is supported; there is a statistically significant positive relationship between the firm's size and a Tier Two Audit Firm selection. In addition, the results show that the ROA variable was significant $(\mathrm{r}=35.829$, sig=.061) at .01 significance level and the Nagelkerke R Square was .063. Accordingly the second hypothesis is supported; there is a statistically significant positive relationship 
between the firms' ROA and a Tier Two Audit Firm selection. Besides, the EPS variable was significant ( $r=1.176$, sig=.045) at .01 significance level and the Nagelkerke R Square was .061. Accordingly the third hypothesis is supported; there is a statistically significant positive relationship between the firms' EPS and a Tier Two Audit Firm selection. Besides, results also show that the foreign shareholdings variable was significant $(r=301.602$, sig=.002) and the Nagelkerke R Square was .223, accordingly the fifth hypothesis is supported, there is a statistically significant positive relationship between foreign shareholdings and a Tier Two Audit Firm selection. In addition, results also show that the existence of foreign members was significant $(r=7.529$, $\operatorname{sig}=.003)$ and the Nagelkerke R Square was .151. Accordingly the eighth hypothesis is supported; there is a statistically significant positive relationship between the presence of a foreign board member and a Tier Two Audit Firm selection.

However, Results show that the ownership concentration variable was insignificant $(\operatorname{sig}=.444)$ at 1 percent significance level and accordingly the fourth hypothesis is rejected. There is no statistically significant relationship between ownership concentration and a Tier Two Auditor selection. In addition, results found that the coefficient of the leverage variable was negative as expected however it was insignificant at .01 significance level ( $\mathrm{B}=-.038$, sig=.377). Accordingly the sixth hypothesis is rejected. This means that there is a negative but non- significant relationship between leverage and a Tier Two Auditor selection. In addition, results also shows that the 
age variable was insignificant at .01 significance level (sig=.830). Accordingly the seventh hypothesis is rejected. There is no statistically significant relationship between Age and a Big Four selection.

The researcher also uses the Multinomial logistic regressions as supplementary test to check the robust of the results after classifying the audit firm into three categories, Big Four, Tier Two, and local audit firms.

The results of running the Multinomial logistic regression using the SPSS are presented in Tables (9) as follows:

Tables (9): Summary of the Multinomial logistic regressions:

\begin{tabular}{|l|l|l|}
\hline Variable & Sig. & Nagelkerke R Square \\
\hline Size & .000 & .169 \\
\hline ROA & .008 & .105 \\
\hline EPS & .004 & .119 \\
\hline Ownership & .551 & .013 \\
\hline foreign Holdings & .000 & .228 \\
\hline Leverage & .323 & .025 \\
\hline Age & .957 & .001 \\
\hline Foreign board & .000 & .209 \\
\hline
\end{tabular}

Table (9) shows the size variable was significant at $1 \%$ significance level (sig=.000) and the Nagelkerke R Square was 0.169. Accordingly there is a statistically significant positive relationship between the firm's size and the Audit Firm selection. Besides, the results also show that the ROA variable was significant at .01 
significance level, with (sig=.008) and the Nagelkerke R Square was 0.105 . Also, results show that the EPS variable was significant at $1 \%$ significance level, with (sig=.004) and the Nagelkerke R Square was 0.119 . Accordingly the there is statistically significant relationship between the firm's profitability and the Audit Firm selection. In addition, results show that the foreign shareholdings variable was significant at 1 percent significance level (sig=.000) and the Nagelkerke R Square was 0.228 . Accordingly there is a statistically significant positive relationship between foreign shareholdings and the Audit Firm selection. Moreover, results show that the presence of a foreign board member was significant at 1 percent significance level (sig=.000) and the Nagelkerke R Square was 0.209. Accordingly there is a statistically significant positive relationship between the presence of a foreign board member and the Audit Firm selection.

On the contrary, results show that the ownership concentration variable was insignificant at 1 percent significance level with (sig=.551). Accordingly, there is no statistically significant relationship between ownership concentration and the Audit Firm selection. Also, results show that the leverage variable was insignificant at .01 significance level with $(\mathrm{sig}=.323)$. This means that there is a no statistically significant relationship between leverage and the Audit Firm selection. Besides, results also show that the age variable was insignificant at .01significance level with (sig=.957). Accordingly there is no statistically significant relationship between Age and the Audit Firm selection. 


\section{7- Summary, conclusions, and suggested future research:}

Actually, auditor selection can be regarded as a matter of audit quality. This Research aims to identify the factors which affect the choice of the Audit Firm in case of an emerging market as Egypt. It provides empirical evidence on the association between the Audit Firm selection and their client firms' characteristics based on a sample of 101 firms listed in the Egyptian Stock of Exchange for the year ended 2013. The hypotheses are tested by using both logistic regression models, the Binary Logistic Regression and the Multinomial Logistic Regression.

In an application of two logistic regression models that tested the determinants of auditor choice in a specific country as Egypt. The researcher can summarize the results of the statistical analysis as follow:

Among the client firms' characteristics, the robustness of the two widely used models indicates that the event of clients' selection of auditors can be predicted by Firm's size, Foreign shareholdings, Membership in the financial sector, and the existence of a Foreign board member. These firms' characteristics are positively and significantly associated with the selection of the audit firm at $1 \%$ significance level. Besides, Egyptian shareholding is negatively and significantly associated with the selection of the audit firm at 1 percent significance level. However, firms' profitability (ROA, ROE, 
EPS), leverage, age, and ownership concentration are not significantly related to the selection of the audit firm in case of Egypt.

In terms of future research, it is also recommended to examine the role that the Audit Committees can play in selecting the Audit Firm. Besides, future researches may also examine the effect of quality of earning and earning management on the choice of the external auditor.

In addition, as the application of this research has taken place on the listed companies in the Egyptian Stock of Exchange, accordingly this research also suggests the application on non- listed firms to know how the situation would be different and this will undoubtedly give a better idea about the auditor selection process in case of Egypt. 


\section{References}

- Abbott, L., Parker S., 2000, "Auditor selection and audit committee characteristics". Auditing : A Journal of Practice and Theory, Fall, 47-67.

- Ahmed, A., Duellman, S., 2007, “Accounting conservatism and board of director characteristics: An empirical analysis", Journal of Accounting and Economics, volume 43, 2, pp: 411-37.

- Anderson, U., Kadous, K., Koonce, L., 2004, "The role of incentives to manage earnings and quantification in auditor's evaluations of management-provided information". Auditing: $\boldsymbol{A}$ Journal of Practice \& Theory, 23, 11-27.

- Aksu M., Onder T., Saatcioglu K., 2007, "Auditor Selection, Client Firm Characteristics, and Corporate Governance: Evidence from an Emerging Market", working paper at Faculty of Management Sabanc1 University, downloaded from: ww.ifc.org/wps/wcm/connect/.../Saatcioglu.pdf?...

- Becker, C., DeFond, M., Jiambalvo, J., Subramanyam, K., 1998, "The effect of audit quality on earnings management". Contemporary Accounting Research, volume 15, 1, pp: 1-24.

- Berton, L. 1995, "Squeeze play: Midsize accountants lose clients to firms both large and small”. Wall Street Journal, (November 14).

- Big Four Firms Network, 2013, "2013 Big Four Analysis". Downloaded from: $\underline{w w w . B i g 4 . c o m}$. 
- Boone, J., Khurana, I., Raman, K., 2010, "Do the Big 4 and the Second-tier firms provide audits of similar quality?" Journal of Accounting and Public Policy, Volume 29, Issue 4, July-August, Pages 330-352.

- Cano M., Núñez M., Sánchez S., 2012, “The value of the auditor brand name for creditors around the world", Public University of Navarra, Department of Business Management, downloaded from: https://www.unavarra.es/dep.../noticeboard contentld...

- Chadegani A., 2011, "Review of studies on audit quality" , International Conference on Humanities, Society and Culture IPEDR, Vol. 20, Pp: 312-317.

- Chen, J., Su, X., Wu, X., 2009, "Forced audit firm change, continued partner-client relationship, and financial reporting quality”. Auditing: A Journal of Practice \& Theory, 28(2), 227246. Available at://dx.doi.org/http://dx.doi.org/10.2308/aud.2009.28.2.227

- Chen, J., Shrome, A., Su, X., 2001, How is audit quality perceived by Big 5 and local auditors in China? A Preliminary Investigation. International Journal of Auditing, 5(2), 157-175. Available at: http://dx.doi.org/10.1111/i.1099-1123.2001.00332.x.

- Citron D., Manalis G., 2001, "The international firms as new entrants to the statutory audit market: an empirical analysis of auditor selection in Greece, 1993 to 1997”. The European Accounting Review, 10(3), 439-459. 
- DeAngelo, L., 1981, "Auditor independence, low-balling and disclosure regulation". Journal of Accounting and Economics, 3, 113-127.

- Dechow, P., Ge, W., \& Schrand, C., 2010, "Understanding earnings quality: A review of the proxies, their determinants and their consequences", Journal of Accounting \& Economics, volume 50, 2, pp: 344-401.

- DeFond, M., 1992, "The associations between changes in client firm agency cost and auditor switching". Auditing: A Journal of Practice And Theory, 11 (1): 16-31.

- DeFond M., Erkens D., Zhang J., 2014, "Do Client Characteristics Really Drive the Big N Effect?", working paper at University of Southern California (June), downloaded from: finpko.faculty.ku.edu/.../DeFond\%20Erkens $\% 20 \% 26 \%$...

- Dopuch, N. and Simunic, D., 1982, Competition in Auditing: An Assessment. In Symposium on Auditing Research. Urbana: University of Illinois, 401-450.

- Einchenseher, J., Shields D., 1989, "Corporate capital structure and auditor fit". Advances In Accounting, Supplement (1): 39-56.

- Fama, E., 1980, "Agency problems and the theory of the firm", Journal of Political Economy, volume 88, pp: 288-307.

- Fama, E. , Jensen, M., 1983, "Separation of ownership and control", Journal of Law and Economics, volume 26, pp: 301325 . 
- Fan, J. and Wong T., 2005, "Do External Auditors Perform a Corporate Governance Role in Emerging Markets? Evidence from East Asia." Journal of Accounting Research, 43 (March): 35-72.

- Firth, M., Smith, A. 1992, "Selection of auditor firms by companies in new issue market". Applied Economics, 24, 247255.

- Francis, J., 2004, "What do we know about audit quality?". The British Accounting Review, 36(4), 345-368.

- Francis, J., Maydew, E., and Sparks, C., 1999, “The Role of Big 6 Auditors in the Credible Reporting of Accruals", AUDITING: A Journal of Practice\& Theory, Vol. 18, No. 2, pp. 17-34.

- Francis, J. and Wang, D., 2008, 'The Joint Effect of Investor Protection and Big 4 Audits on Earnings Quality around the World'. Contemporary Accounting Research, 25 (1):157-191.

- Francis, R., Wilson, E., 1988, "Auditor Changes: A test of theories relating to agency cost and auditor differentiation". The Accounting Review, (October): 663-682.

- Guehami, O., Pittman, J., Saffar, W., 2009, “Auditor choice in privatized firms: Empirical evidence on the role of state and foreign owners". Journal of Accounting and Economics, 48(2), 151-171.from http://dx.doi.org/10.1016/j.jacceco.2009.08.003

- Healy, P., Lys T., 1986, "Auditor changes following Big-Eight takeovers of Non-Big Eight Firms". Journal of Accounting \&Public Policy, winter,251-265. 
- Hooghiemstra R., Hermesa N., Oxelheimb L., Randøyc T., 2015,"The Impact of Board Internationalization on Earnings Management", downloaded from: www.efmaefm.org/0EFMAMEETINGS/EFMA\%20ANNUAL\%20MEET

- Ianniello G., Mainardi M., Rossi F., 2013, “Corporate governance and auditor choice", Italian Academy of Business Administration and Accounting, Bicentenary Conference- Lecce, Italy, September 19 -21 , downloaded

from:

ww.aidea2013.it/docs/270 aidea2013 accounting.pdf

- Johnson, W. , Lys T.,1990, “The market for audit services: Evidences from voluntary auditor changes". Journal of Accounting And Economics, January,281-308.

- Johnstone, K. 2000, "Client-acceptance decisions: Simultaneous effects of client business risk, audit risk, auditor business risk, and risk adaptation". Auditing: A Journal of Practice \& Theory, 19 (Spring): 1-26.

- Johnstone, K., Bedard, J., 2004, “Audit firm portfolio management decisions". Journal of Accounting Research, 42(4), 659-690.

- Kim, J., Chung, R., Firth, M., 2003, "Auditor conservatism, asymmetric monitoring, and earnings management". Contemporary Accounting Research, 20(2), 323-359.

- La Porta, R., Lopez-De-Silanes, F., Shleifer, A., Vishny, R., 2002, "Investor protection and corporate valuation". Journal of Finance, 57(3), 1147-1170. 
- Lennox, C., Pittman, J., 2010, "Big Five audits and accounting fraud". Contemporary Accounting Research, 27(1), 209- 247.

- Leung N., Cheng M. 2014,“Corporate Governance Mechanisms and Auditor Choice: Evidence from China", International Journal of Business and Management; Vol. 9, No. 9; 41-56.

- Lin, Z.J., Liu, M. 2009, "The impact of corporate governance on auditor choice: Evidence from China”, Journal of International Accounting, Auditing and Taxation, Vol. 18, 44-59.

- Oxelheim, L, Randøy, T., 2003, "The impact of foreign board membership on firm value", Journal of Banking \& Finance, volume 27, pp: 2369-2392.

- Palmrose, Z., 1988, “An Analysis of Auditor Litigation and Audit Service Quality”. The Accounting Review, 64(1), 55-73.

- Raghunandan, K., Rama. D., 1999, "Auditor resignations and the market for audit services". Auditing: A Journal of Practice \& Theory, 18, 124-134.

- Rodríguez C.,and Nickel N., 2009a, "Big 4 Audits and Conservatism: The Trade-off between Audiror's Litigation Risk and Client's Information efficiency". Working paper at University Carlos III of Madrid, downloaded from: 22financeforum.unizar.es/.../22financeforum submissio...

- Rodríguez C.,and Nickel N., 2009b, "How are Big 4 Audits Valued Around The World? The Non Linear Relationship between the Value of Audit Quality and The Investor Protection Quality", research project of the General Secretary of Universities, Research 
and Technology of Andalucía and Spanish Ministry of Science and Education, downloaded from: 22financeforum.unizar.es/.../22financeforum submissio...

- Simunic, D., Stein, M., 1987, "Product differentiation in auditing :a study of auditor choice in the market for unseasoned new issues", Canadian Certified General Accountants' Research Foundation.

- Simunic, D.,Wu, X., 2009, "China-related research in auditing: A review and directions for future research". China Journal of Accounting Research, 2, 1-25.

- Srinidhi, B., Gul, F., Tsu, J., 2011, "Female directors and earnings quality". Contemporary Accounting Research, 28(5): 1610-1644.

- Teoh, S., Wong, T., 1993, "Perceived Auditor Quality and the Earnings Response Coefficient", The Accounting Review, Vol. 68, No. 2 , pp. 346-366.

- Thornton, D., Moore G., 1993, “Auditor Choice and Audit Fee Determinants, Journal of Business Finance and Accounting, 20 (3),306-349.

- Wang, B., and Qingquan, X., 2011, "Auditor choice and accruals pattern of cross-listing firms", China Journal of Accounting Research, 4(4), 233-251.

- Watts, R., Zimmerman, J., 1981, “Auditors and the determination of accounting standards". Working paper, University of Rochester. 